\title{
Enkulturatsiooni kriisi usutunnistust otsides
}

\author{
(Mõtted, mis tekivad ühe Setumaa ekspeditsiooni lindistuste litereerimisel.) \\ Aivar Jürgenson
}

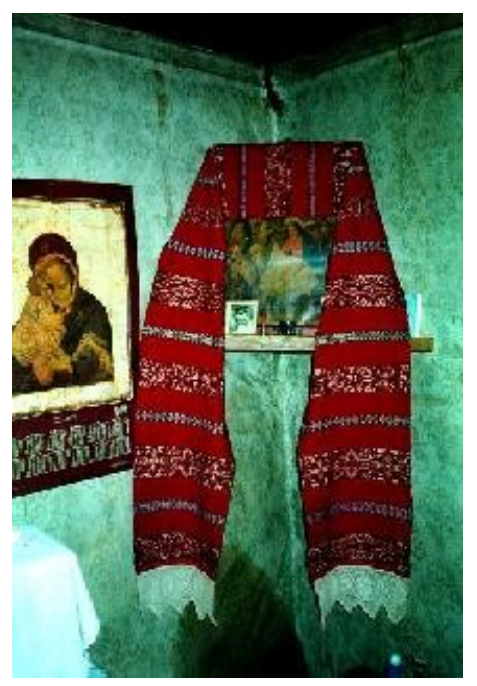

Das älteste Denkmal zeigt uns noch nicht das Ursprüngliche, wir nähern uns ihm nur gradweise, indem wir immer weiter zurückgehen.

(Jacob Grimm "Kleinere Schriften", Bd. 4, 1884, S. 551)

1996. aasta suvel teostatud välitöödel Setumaa Pihkva oblasti territooriumile jäävas osas kogusin suulist pärimust peamiselt eksitajafenomenist. Loomus oli igas mõttes korralik, kuid võrgusilma suurust arvestades üsna ühte sorti - eks ta nii ju mõeldud olnudki. Ometi jäi võrku lisaks hulgale eksitajalugudele muudki, mida kohe kuidagi prügikalaks pidada ei saa. Ja isegi kui miski esmapilgul sellena tundus, võis ta hiljem väärtuslikuks osutuda. Ja sugugi mitte konjunktuuri muutlikkuse tõttu. Ülihoolas diktofon püüdis kinni eelnimetatud teemat puudutavate muistendi- ja memoraaditekstide seisukohalt sekundaarset infot, mis hiljem, lintide kuulamise ja litereerimise käigus mõningaid mõtteid tekitas ja käesoleva kirjatüki algtõuke seisukohalt primaarseks osutus.

Alljärgnevalt tuleb juttu uskumisest ja naerust, pärimusest ja järjepidevusest, rääkijatest ja räägitavast, kuulajast ja temas tekkivatest meeleoludest. Ei söandaks väita, et see, mida nende märksõnade all vaadelda püüan, alati ja igas seoses setulik on, et mõtted, mis üht eurojooksule jalgujäävat väikest kultuuri uurides tekivad, ainult setusid mõtestavad. Nii ei julgekski järgnevat nimetada mingitpidi setu ilmavaadet kajastavaks. Selleks pole mingit alust. Puudub ka põhjus või vajadus, sest setu ilmavaade on setude endi asi. Ja nende esivanemate asi. Pealegi: usutunnistus (kõige laiemas mõttes), see, mida keegi usub, see, millise nurga alt seda maailma näeb, pole kaugeltki igas seoses samastatav sellega, mida kirikus kooris loetakse.

On inimlik pidada tõepäraseks, seega siis olevaks, meeltega referentsraamidest läbipressitut: ainult see on, mida meeled vastu võtta suudavad ja mõistus ilmavaatele kohandada oskab. Viimase igikestvas staatilisuses on aga põhjust kahelda. Seega siis see, mis on meie jaoks, pole hoopiski sama, mis on kadunud sugupõlvedele. Viis, kuidas suur osa tänastest informantidest edastatavasse materjalisse ise suhtub, tema uskumise aste või kraad, ei saa olla adekvaatne paari sajandi tagusega. Pärimuslik maailm, millest materjali kogume ja selle põhjal järeldusi teeme, on mingi astme derivaat kunagisest, aja ja mõtte sõelast läbilitsumisega killunenust, ja killud lootusetult segi. Neid segiaetud kilde silmitsedes ja peost pihku kallates loodetakse tabada mingi hetkeks sähvatav konfiguratsioon ja see fikseerida. Hea silm peab selleks olema. Ja mälu. Kummatigi ärgu keegi arvaku, et on jõudnud algusse. 
Alustaks õige seda juttu naeruga. Informant naerab. Selles pole tegelikult midagi erilist. Naer on inimlik. Naerdakse ju peamiselt siis, kui miski nalja teeb. See on triviaalne, seda ei tasu mainidagi. Ometi pole nali ainus naeru esilekutsuv universaal. Iga grimass ei väljenda veel naeru nalja pärast, iga kramp kõhus ei ilmuta lõbusust.

Küllap on iga välitöödel käinud usundiuurija olnud tunnistajaks olukorrale, milles informant, rääkides mõnest usu objektist või nähtusest, ilmsete vastuoluliste tunnete küüsi sattudes naerma hakkab. Ja kui on mitu informanti, siis naerdakse kooris. Teadmata, mis salapärane jõud see on, mis muidu igatpidi ontlikes inimestes sellist kummalist refleksiooni esile kutsub, satub ka küsitleja eriskummaliste jõudude meelevalda. Ei, mitte et naerma ajaks. Hoopis kõhe hakkab.

Lintidelt usundilisi tekste litereerides tundusid siin-seal juttu katkestavad naerupahvakud kuidagi eriti kohatud ja, mis siin salata, ka naljakad. Nüüd, kabineti kaitstuses ja kindlate seinte vahel jutte kuulates, nüüd, mil naer ja küllap ka seda põhjustav salapärane jõud kindlalt makilindi metalses haardes vangis, nii et ta enam kuulajat - antud juhul mind - mingi fluktueeriva otsemõjuga üllatada ei saa, on sobiv aeg fenomeni lähemalt vaadelda.

Võtan eelduseks, et naeru otstarbe mõistmiseks antud situatsioonis tuleb kõigepealt lahti saada jäikadest assotsiatsioonidest naeru ja nalja vahel või vähemalt tunnistada võimalust, et igas seoses ei tarvitse naeru põhjuseks olla lõbus tuju. Naeru usundiloolistele, rituaalsetele tagamaadele on tähelepanu juhtinud V. Propp. Tema hinnangul on naerul igas kontekstis oma tähendus. Nii kehtis naeru keeld seal, kus surnute maailm lõikus meie omaga. Propp oletab motiivi võimalikke seoseid shamanistlike kujutelmadega hingerännakust. Kui elav satub mõnes muinasjutus surnute ilma, peab ta oma elusust, st. tõelist olemust varjama. Naer kui elususe atribuut reedaks ta surmkindlasti. See süzhee on eriti levinud Põhja-Ameerika indiaanlaste müütides. Mõnes loos püüdsid surnud tulnukat kontrollida, st teda naerma ajada. Eskimotel on lugu, milles shamaan läheb ülailma ja näeb seal üht trummi taguvat vanaeite. Ta on naljakas ja ajab naerma. Shamaan pahvatabki naerma ja muidugi reedab end sellega. Eit viskab ta maa peale tagasi. Vene folklooris on selle vanamuti vasteks V. Propi arvates Baba-Jagaa oma tuntud nõudega: "Kui tuled tarre, vaata, et ei naera!" Propp toob näiteid, milles noorukite initsiatsiooni ajal kehtib naerukeeld (kvakiutlitel, ühel Okeaania saarel). Samas esitab ta näitematerjali ka naeru kasutamise kohta maagilise instrumendina: naerdes tapeti vanureid, naerdes tapeti loomi, naerdes külvati põldudele vilja. Maagia aluseks on kontseptsioon naeru elustavast, elu jätkavast, elu edendavast väest (Propp 1976: 178-192). Propile viidates võiks siinkohal tuua veel hulganisti analoogilisi näiteid, kuid usun, et sellestki piisab veenmaks lugejat, et naerul on naljafunktsiooni kõrval alternatiive.

Et lähemale tulla meid huvitavale probleemile, st miks informant uskumist ja seega siis ehk ka austavat suhtumist eeldava materjali esitamisel naerab - selle asemel, et võibolla hoopis pühalikku hardust tunda - tuleb minu arvates ühena kõne alla naeru pingetmaandav funktsioon, lahenduse pakkumine vastuolulistele tunnetele. Seega siis reflektiivne, psühhofüsioloogiline funktsioon, vähemalt esmapilgul tahtest sõltumatuna näiv.

Naeru seostatusele vastuolulisusega, aga ka nähtuse degeneratsiooniga, on viidanud Herbert Spencer (Spencer 1939). Iga juhtumuse muutumine suurest väikeseks, väärtustatust väärtustamatuks, ohtlikust ohutuks võib tekitada kergendava olukorra, mõjuda koomiliselt. Väljanaerdav sünnib madaldudes, suure ja väikese loogika vastuolulisuses. Taoline naer tekib 
pinevuse ning lõdvestumise füsioloogilise reaktsioonina. Psühholoogilist vastupidisuse mudelit (naer kui kergendus) võib ühitada nii kergendus- kui üleolekutunde mudeliga. Kui mingi väärtust kandev tähtis entiteet äkki kaotab iseloomuliku omaduse, võib olukord vaatlejale mõjuda koomilisena. Ta naerab ja tunneb heameelt üleolekust (Knuuttila 1992: 106-107).

Välitöödel salvestatud lindistusi kuulates torkavad silma (tegelikult kõrva) sagedased naerupahvakud mütoloogilistest olenditest rääkimisel. Kui tegemist näibki esmapilgul olevat suuresti reflektiivse käitumisega, ei saa alateadlikku tahtelisust ühe võimalusena ometi välistada. On ju selge, et kui mingit kuuldud informatsiooni (eriti negatiivset) ei usuta või ei taheta uskuda, siis on esimene reaktsioon sageli : "Mis sa naljatad!", "Ära tee nalja!", "See on ju nali!" Või lihtsalt naerdakse. Vormelid, mis tavakasutuses omavad üht tähendust, kannavad teinekord maagilist funktsiooni: see, mille aktualiseerumine on ohustamas või ongi kardetu juba aset leidnud, kuid esialgu veel empiirilise kinnituseta, püütakse mittereaalsusse jälle tagasi tõrjuda. Eks seegi ole maagia.

Teine ja minu meelest küll sagedasem põhjus mütoloogiliste teemade väljanaermisel, naeruvääristamisel, on valdkonna otsene väljalibisemine reaalsuse sfäärist. Hirmutavast või lihtsalt salapärasest on demütologiseerumise, degradeerumise käigus saanud väljanaerdav ja kuigi väljanaerdava ja mitteusutava vahele ei saa eeltoodud väiteid arvestades võrdusmärki panna, arvan siiski, et enamikel juhtudest on selline naer ilmlikustumise, religioossest maailmapildist kaugenemise indikaatoriks.

Naer võib samas seoses olla ka enkulturatsiooni kriisi indikaatoriks. Ta näitab, et enam ei hinnata traditsionaalses kultuuris autoriteete, ei austata seda, mis võibolla on traditsiooni peamine püsiväärtus, tugi, milleta kultuur vaikselt oma identiteeti minetama hakkab. Enkulturatsiooni toimemehhanismides on aset leidnud süsteemi sisuliselt halvavad muudatused. Vanem generatsioon ei suuda nooremat enam sundida traditsionaalseid mõtlemis- ja käitumismalle üle võtma. Ja kui ta seda püüab, siis on põlvkondade konflikt kohe

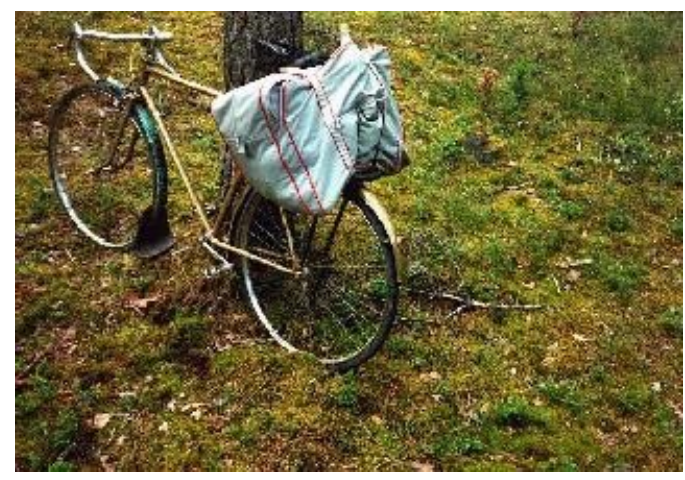
kaelas. Viimase olemust on Margaret Mead seletanud nii: Tänapäeval pole kogu maailmas selliseid vanu, kes teavad, mida lapsed teavad. Varem, kui elati suletud kultuurisüsteemis, oli ikka vanu, kes teadsid rohkem kui kõik lapsed. Tänaseks on selline situatsioon möödas. Mitte ainult, et vanemad poleks enam eeskujuks, vaid nad pole üldsegi enam õpetajaid, nõuandjaid. Ükski vanadest ei tea seda, mida teavad viimase 20 aastaga pealekasvanud noored (Mead 1971: 110-111). See konflikt ei tarvitsegi väljenduda nii äärmusliku trotsina, nagu näiteks Tõnu Õnnepalu oma "Piiririigis" ühel tegelasel öelda laseb: "Ma olen üritanud kõike vastupidi teha kui vanaema õpetas." Ei, väärtused teisenevad tasa ja targu, aga seda järjekindlamalt ja globaalsemalt. On ju üsna tavaline, et seda lugu, mida rääkis kord vanaisa - ja tema kuulis seda muidugi oma vanaisalt, see oma vanaisalt ja nii edasi (õigemini: "ja nii tagasi"), - ei võeta enam vastuvaidlemist mittekannatava aksioomina, vaid seatakse talle vastu kõikvõimalikud selle maailma tarkused, mis imetud hariduse lutipudelist. Ja seda vähimatki aukartust tundmata. Kooliharidus on lapsed targaks teinud ja (esi)vanemad rumalaks.

Nii andis asjakohast teavet pärimuse iseloomust üks elunäinud informant (M, sünd. 1924). Küsimusele, kas kellelgi puuk on, vastas ta, et see oli vanasti, nüüd on rahvas targem, vanasti oli 
rahvas ikka lollim. Vaata minu põlve, ta... Minu emagi! Ei olnudki koolis käinud, ei olnd kooliharidust. Nendele üks loll rääkis ja... ja teine rääkis jälle edasi ja.

Teine (M, sünd. 1933) räägib vanasti elanud rahva rumaluse iseloomustamiseks kunagi kuuldud/loetud loo: Väljas olid palgid virnas. Tuleb üks mees oma naisega. Näevad palki, millele oli lehm hunniku teinud ja mis nüüd palgivirna otsas oli. "Vaata, oh sa taevaisakõnõ, kus saab loom sinna sittuda näet sinna palke pääle? " Oli selline rumalus.

$\mathrm{K}$ : Millal see rumalus siis ära kadus?

I: Ikka jo... eesti aigu. Ma i oska ka üldä, see, ütle nii, katekümne aasta... üts juba noh, see nakas ju kaduma nii sada aastat tagasi või juba... sis nakas juba rumalust kaoma, nakasi inemised õige... sada aastat tagasi.

Viimatitsiteeritu pidas rumaluse kadumise põhjuseks seda, et siis tuli sundkorras koolis hakata käima. Nii on siis lood traditsiooni ja autoriteetidega. Ja naeruga on siin niipalju tegemist, et kui siis üks vanaema või vanaisa mõnda muistendit usutavana paista tahab lasta, on reaktsiooniks üleolev muie või naer. Kui nimetatud esivanem juhtumisi leplik inimene on - st püüab vältida lahvatadaähvardavat konflikti - naerab ta ise ka kaasa.

Kui taas tagasi tulla eelkirjeldatud põlvkondade-konflikti põhjuste juurde, võib ühe nüansina välja tuua just enkulturatsiooni sanktsioneerija, st vana põlvkonna usklikkuse astme kui määrava teguri järjepidevuse tagamisel, sest eks sõltu usust ka konformsus. On nimelt põhjust arvata, et kui üks vanaisa oma lapselapsele muistendi räägib ja see seda naeruks võtab, ei pea põhjuseks alati olema lapselapse jäikus või liigne selle-ilma-tarkus, vaid esitaja enda kõhklev hoiak jutustamisel. Väriseva ja jõuetu käega tehtud külv ei saagi idaneda. Lapse naeruga lepitakse, sest sisimas ei usuta ka ise. Ja nii rõkkab kogu tare naeruhelides.

\section{Helidest. Jumalik ja inimlik aspekt}

Võiks üritada kultuuri lineaarset kulgemist tõmmata inimese arengu bioloogilisele liistule. Naer ja üleolevalt heatahtlik hoiak esivanemate uskumuste suhtes veenab siis traditsiooni vananemises, täiskasvanuks saamises. Täiskasvanul ei sünni uskuda viruskundrat või rukkihunti ja ta ei näe neid. Laps aga näeb ja usub (või: usub ja näeb). Nii ei usu kaasaegsed pärimusekandjad suuresti enam normaalsele mõistusele võimatute asjade võimalikkust. Üks osa maailmast on sellega nende jaoks lukku pandud.

Lutebäst näed läts taha om ütesä kilomeetrit Verska minnä. Tuu mu tädipoig, pümme - tal oll kats poiga pümme - ja lihavõtte üüsel läts kerikohe minämä. Vot, no üüse tuu... Verska kerikohe ja - esi om pümme - ja ütel, kurat, et pini... kurat, hunt tul'l tii pääle kõrvale kurat... ette. Hunt. Ta tahtnud hunti ka minämä... aga hunt /.../ kõrval. A' tuu kuradi küläpoiss, nuur, tull'gi tagasi! Ja tuu ütel: "Mis sa tagasi tullt? "- "A' hunt lasõ's minnä. " - "Kuidas sa näed? Tuu olõs määnegi hunt. " - "A' mine kae. " Hommugu tulõs kaema, ikka hundi jälled... värske lumõ pääl. Noh, lihavõ/--/, värske lumi kah. Ja oligi hunt ikka... kõrval. No ta tuli är' kodo. Julgõs minna'õi edesi. Hunt aste kõrval. Küsitleja: Lihavõtte üül, jah, kerko es saa minna?

Jah. Ja timä oli pime - noh, na oli sündünü pime, a ta käve Verskah, nii Saatse.

Küsitleja: Ja kus ta teadis, et hunt siis oli?

Ma'i tiiä. Ütles, et timäl om jah /--/ kuulmine hää. Tal om nii hää kuulmine, et ta vist kuuld, et kõrval ast... 
Näib, et teaduslik ilmatunnetus on tegelikult ilma tunnetus: tunnetusprotsess toimub suuresti ilma asjakohaste ja vahetute instrumentideta, ümbritsevat tajutakse mõistuslike abstraktsioonide varal. Meeled on vähemalt osaliselt maailma mõistmise algoritmist välja jäetud. Tulemuseks on degenereerumine: iga nägemine kaob viimaks, kui teda kaua pole kasutatud. Nägemist ei tarvitsegi alati kaudsena, meelte üldise sünonüümina mõista, ta on ka otseselt meelte seas esimene. Ühe teooria kohaselt olevat nägemine olnud enne kuulmist. Põhjenduseks tuuakse tähelepanek, et osal inimestest puudub absoluutne kuulmine. Kui see teooria nüüd vett peaks ja nägemine tõesti nii vana on, siis võib ju järeldada, et nägemise aeg hakkab vaikselt otsa saama. Igal asjal oma aeg.

Silm võib olla selge või tuhm, nägemine hea või halb, aga nägemist peetakse kuulmisest vahetumat kontakti võimaldavaks. Selles, mida nähakse, ollakse rohkem kindel kui kuuldus. Kuulmine seeeest võimaldab ka kaudset kontakti: mingit üleloomulikku kogemust, olgu ta ilmutatud visuaalsel või auditiivsel kujul, vahendatakse valdavalt auditiivselt, pärimuses muutub ka visuaalne elamus auditiivseks. Kui inimene, kes on näinud midagi mõistusevastast, püüab seda teistega jagada, peab ta sellest rääkima. Edastatava usutavus võib iga järgmise rääkimisega väheneda. Üleloomulikku ilmutust vahendavad esimesest lülist viimasena erinevad meeled, erinevad inimesed. See, mis alguses võis olla nähtu, kandub edasi kuulduna ja viimseks produktiks on üks ... kuulujutt. On ütlematagi selge, et sõnade nägemus ja kuuldus semantiline kate on erinev. Nägemust võib nägija pidada jumalikuks ilmutuseks, kuuldust kuulja turunaiste lobaks. (Muidugi, kui Freud oma hiilival sammul vahele ei astu ja kõike tühjaks ei tee.)

Kui üks lugu degradeerub kuulujutuks, pole põhjus alati loos endas, vaid interpreteerijas, kommunikatiivse kanali nii-või naasuguses häälestatuses. Lugu on kui üks kodutu hulgus, kes oma sihitutel rännakutel on öömajal kord siin, kord seal. Igas paigas jätab ta midagi maha, igal pool saab midagi teele kaasa. Muutumata ta ei jää, sest paigal püsida ta ei armasta. Ta väsib, siis saab jälle kosutust, st lihtsustub, komplitseerub, kristalliseerub mõneks ajaks, aga siis muutub taas. Vahepeal teeb läbi olemusliku transformatsiooni, st. muutub näiteks muistendist naljandiks või muinasjutuks, säilitab aga siiski essentsi, mis võimaldab olude muutudes taastada varasema zhanrilise kuuluvuse.

Ilmutusliku heli ja kuulujutu vahel on tükk tühja maad. Helist sünnib sõna või õigemini: sõna ei saaks üldse eksisteeridagi ilma helita; heli sõna instrumendina teeb viimase võimalikuks. Vist kõik maailma rahvad on millalgi uskunud mõtete või emotsioonidega täidetud heli korrastavat väge, vist kõigi rahvaste kosmogooniates on helil loov tähendus. Olgu siis Sõna, Laulu või - ütleme näiteks Naeru kujul. Nii on hellenistlik-kristlikus traditsioonis Sõna loov alge. Hindudel on ütlus: "Suur Laulja ehitas maailmad ja Universum on Tema Laul." Ühes kreeka-egiptuse traktaadis maa loomisest pahvatas jumal seitse korda naerma ja tekkis jumalik seitsmik. Seitsmendal korral naeris jumal rõõmust ja sündis psyche. Togost pärinevas müüdis lõi jumal algul mehe, siis naise. Need vaatasid üksteisele otsa ja puhkesid siis naerma. Pliniuse teatel naeris Zarathustra sündides (Propp 1976: 187).

Niisiis on tähenduslik heli jumalik, loov ja kosmostav alge või instrument. Samas on ta ka inimlik, asi, mis puudutab inimeseksolemist kõige lähemalt ja otsesemalt: argitajutavat maailma sisustavatest olenditest on inimene ainus, kes valdab kunsti, kuidas helidest sõnu teha, kuidas enda olemise eripära oma liigikaaslastele sõnades väljendudes jagada. Inimene tunneb end ses mõttes ainsana, sellest tulenevalt ka erilisena. Niisiis on heli inimlik ja see aspekt välistab teatud mõttes tema eelväidetud jumalikkuse. On ju teadupärast möödas aeg, mil linnud ja loomad veel rääkisid. Selles tõdemuses väljenduv globaalne pessimism on tegelikult üldistus, maksiim, mis võimatustab 
ürgalgusliku kohalolu siin ja praegu. Kogu maailm manifesteerib, et nüüd enam linnud ja loomad ei räägi, nüüd enam jumalad ei loo naerdes maailmu, vaid magavad norinal (heli seegi, kuid kui mannetu!), nüüd on degenereerunud heli vaid eksitus ja helist moodustunud sõna vaid üks kuulujutt. Või on eksitus koguni nii suureks saanud, mateeriat liigitav ürgne heli nii kõveriti suundunud, et järeldatav mõju on veelgi halvem: alles on jäänud sõna kuri vägi, maagiline pahategev jõud. Nullpunkti vaibumise asemel jõuline miinusskaalale tung. Küsimus on uskumises.

\section{Uskumisest}

Muistendi kriteeriumiks peetakse tavaliselt tema usutavust. Fr. Ranke, esimese muistenditeoreetiku meelest on muistend objektiivselt ebatõese sisuga rahvajutt, mida esitatakse sellisena, nagu temas kirjeldatud sündmused oleksid tegelikult aset leidnud. Von Sydovi määratlus on analoogiline. Tema arvates ei peegelda muistendi sisu objektiivset tõde, aga ometi nii rääkija kui kuulja usuvad. Kui tänapäeval on mitmed uurijad usutavuse kriteeriumi muistendi puhul ebapiisavaks kuulutanud ja muid võimalusi välja pakkunud (Degh, Vazsonyi, 1981: 94), on see ikkagi vaid konkreetsete fikseeritud rahvaluuletekstide lahterdamise probleem ja ei enamat. Usku kõrvale jättes vabanetakse küll ühest tülikast ja tehnilistele mõõteaparaatidele mittealluvast teksti komponendist, kuid ta jääb alles, küsimata, kas ta arvatakse lahterdamisele alluvat või mitte. Kui ta võetakse ära kartoteegikastidest, ei kao ta pärimusekandjate hingest (või südamest - kes küll määraks usu asukoha inimeses?) kuhugi.

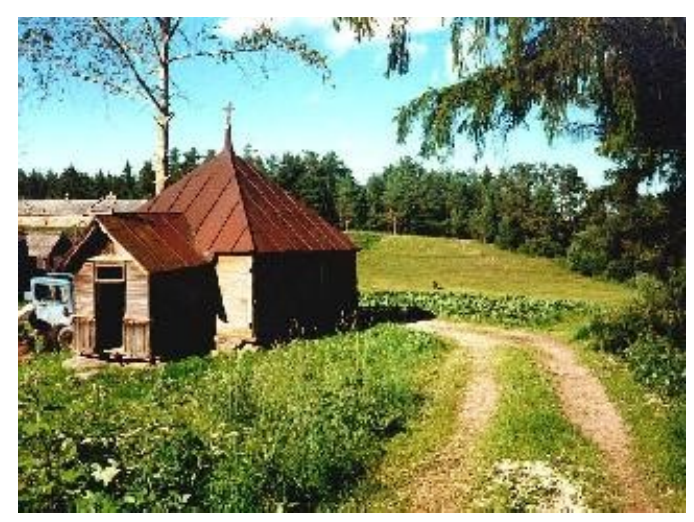

Autoriteedid on kui sammas, mille ümber saab maailma korrastada. Setudele on autoriteediks kirjasõna (piibel) ja vanarahva tarkus 'a la mis vanõmba rääkisi, mis süo maailm om. Kohati need kaks argumentide kategooriat kattuvad, jätmata teineteisesse sulandudes võimalust aru saada, mis siis konkreetsel juhul tõe tõelisust garanteerib. Aga sel pole ka tähtsust, sest nagunii on nii fikseeritud sõnale kui traditsioonile viitamine rohkem metafoori väärtusega: kui keegi vanamemm ütleb, et tema poolt väidetu on piiblis kirjas, ei tähenda see tingimata, et ütleja seda piiblist lugenud on. Ka vanarahvale kui mingile paikapanevale suurusele apelleerimine ei too tavaliselt kaasa täpsustavat seletust. Kui piibel ütleb, siis on nii. Kui vanemba rääkse, siis on nii ja nii ka jääb. Kui iga usuväide vajab alateadlikku kinnitust ja viidet autoriteedile, siis ka see on nii ja jääb alati nii olema.

See, et usutavust on vaja rõhutada loo kuulajale, on asja üks tahk. Selle kõrval tuleb arvestada ka võimalusega, et jutustaja vajab ka ise kinnitust. Iga uus jutustamine toob vältimatu osana kaasa vajaduse jutustatav lugu uuesti elustada, uuesti tema sündimisele kaasa aidata. Autoriteetsele allikale viitamine on selle initsiatoorse akti oluline vahend.

Kinnituse või tõestuse otsimises eelmistelt põlvkondadelt väljendub ühtlasi globaalne pessimism, see, mis ilmselt kõigile rahvastele omase usuna sisendab pideva kaugenemise, võõrandumise, mandumise tunnet. Otsitakse ja oodatakse kinnitust neilt, keda peetakse traditsiooni autoriteetideks, neilt, kes jutustatavates lugudes asetleidnud sündmustele lähemal, neilt, kelle usu suure kontsentratsiooni võimaldas ajaline lähedus sündmuse sünniga. (Sündmuse kui sellise omapära selles ongi, et ta sünnib, ei sure aga iialgi. Kaugeneb vaid.) 
Minu meelest seostub mineviku õilistamisega ka tubli annus eetikat, ometi mitte tavatähenduses. (Eetiline silm-silma-vastu seadus pole päriselt seesama mis head tegema - vt. Masing 1995: 13). Kui setu võrdsustab uskliku ja hea inimese, siis vaid sekulariseerunud ühiskonnas võib see arusaamatu tunduda. Samas: kui setu ütleb, et usklikud nägid üleloomulikke olendeid, kusjuures nägijad olid head inimesed, siis selles seoses ei maksa mu meelest omadussõnale "hea" anda tavapärasesse eetikavaldkonda kuuluvat sisu, vaid otsida seost sealt, kus headus ja usk kokku jooksevad: Jumal on hea. Nii on headus selles seoses jumalik substants, miski vägi, mis annab silmad, aga ühtlasi ka teise maailmatunnetuse, mille üheks väljenduseks on armastus loodu vastu, st. headus. Kurjus ja usk ei käi kokku ja tige usklik on üks hirmus olend.

Seda... seda rääkis... seda rääkis minu... minu ema ja isa noh, siis... mina ise ei tundnudki seda inimest. No mina olin siuke... kuis neil see jutt käis. Noh, olen seda vanainimeste juttu kõrvalt kuulnud ja... ja isa on rääkind sedasi. Ja... vot seda Läppasood või seda kanti peeti ka selliseks, et säält tulid ikka nagu kuradid välja, jooksid alasti. Või sääl, kus oli sauna... Kuradid jooksid sauna ja... ja...ja...ja käisid, et pimedas ei julgend sauna minna naised.

Küsitleja: Et keegi oli näinud neid?

Jah. /.../ et keegi - jälle ma ei tea nime - noh, peeti väga siukseks usklikuks inimeseks, et-et ainult need nägid, kes väga uskusid ja-ja kes olid väga siuksed head inimesed, et need ainult nägid neid kuradeid. Ega... ega igaüks ei näinud. Et tema oli nagu siuke ettenägeja või-või-või ettenägija, aga nii et... võibolla see Anne tõesti (naaber?) oskab öelda nimesid ka, kes... kes see oli. See oli sealt, kas... kas ta oli sealt Sokolova poolt või... või-või-või noh... see on nii minu kõik lapsepõlvest kuuldud. Et-et tema on näinud, et kui rahvas saunast ära on läinud, et... et noh, sealt Läppäsoost on siuksed kuradid välja hüppand, pruunid ja saba taga ja jooksnud sauna. Ja kui... ku tema on näinud, siis peale seda ongi olnud jälle mõni õnnetus või-või-või asi või-või siuke...

William Blake on öelnud, et Jeesus ei saanud teha imesid uskmatuile. See tähendab siis, et inimene, kes arvab, et imede aeg on lõppenud, on võtnud endalt võimaluse kogeda imet. Võimatu näib saada uskumise tulemust uskumata (Masing 1995: 297).

Kui ühes tondijutus kirjeldatud kriitilisel hetkel käitub peategelane vastavalt traditsioonis omandatule, siis seob mõlemat - nii traditsiooni kui tegutsejat mingi eriline side, mis lisaks nende (vanade, endiste) sidumisele tõmbab nende ja uue aja ilmanägemise vahele piiri (ei hakka siin pikka lugu jutustama, toon vaid enda meelest olulise): Vanaisa magas rehes ja kuulis ühtäkki, kuidas killõ tull rehe nulka pite üles ... a timä ol'l vana inemine ja timä tegi risti pää alla ja heit risti ette.

Omadussõna vana semantiline väli hõlmab lisaks bioloogilisele määratlusele ka kultuurilise vastanduse: vanaaja inimene käitub teisiti kui tänapäevane, vana on ka see, kes esindab vana mõttelaadi, vana usku. Aga võib arvata sedagi, et ilma mitmetähendusliku vanaolemiseta poleks ta killõt kuulnudki.

Just mitmetähenduslikkust tuleb vanaolemise juures rõhutada, võiks ju muidu tekkida ekslik arvamus, nagu moodustaksid kõik pensioniealised mingi pühendatute

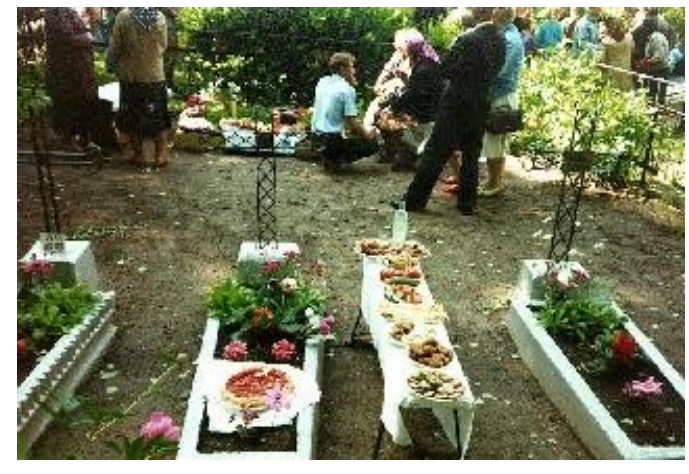
korporatsiooni, mille liikmed kõik kuidagi paremad, usklikumad, nägijamad on. Seda pole isegi Setumaal. Uskumise skaala mõlemad otsad on üksteisest üsna kaugel, suhe sellesse, mida silma- või kõrvaretseptorid tavaolekus ei registreeri, on isikuti vägagi erinev. Erinev seega siis usutunnistus. 
Nii näiteks kohtusin vana naisega, kes kogu oma rikkaliku jututagavara juures ei tahtnud vanakurja nimegi suhu võtta. Ühelt poolt tegi see asjaolu küsitlemise (vähemalt alguses) pisut katkendlikuks jutus sageli esinevad eufemistlikud *"see" ja "too" vajasid ju täpsustamist -, teisalt mõjub sellisel kujul tunnistatud usk üpris ühemõttelisena. Aga skaalal on ka teine ots ja sinna või sellele üsna lähedale näib asetuvat järgmise loo jutustaja. Loo enda teemaks on eksimine, aga ärgu lastagu end sellest eksitada:

Ütskõrd, kurat, tul'l vot tüükoha tul'l miilde tuo see masina pääl tüüdi. Kaurik ütel, mingui sa minema õdagu. Lase sääl pool liitrit viina, kurat, jõime sää... kroshkat ja... et ma vot, oh kurat, mõista nüüd tüükohast kodo tulla läbi mõtsa. Kas ta... kats kõrda sai ta Pelska ujani näet sialt tulõ Taelova alt... kats kõrda sai sinna oja mano, kurat. Ma läe üle oja, mul pole vaja minna, kurat. Tulõ üles, jäll ki sääl oja mano, kurat. Nii ku valges lõts süo...

Küsitleja: See oli kogu öö siis või?

Piaaegu, kell oli neli, kurat, kaet, ahah, linna valu on, kurat, panne siit otse linnapääle, sai taha Kossomolka maja manu vällä. Sial sis oli selge pilt.

Küsitleja: A' mis selle kohta räägitakse, kes see eksitab?

Mina es näe teda, kurat. Kedägi.

"Kuradeid" ses jutus vaevalt palvevormelitena võtta võib, kuidagi nad siiski eelneva teemaga ühilduvad.

Usutunnistusena võib võtta sedagi, kui mõni informant suudab ühte panna nähtused, mis haridusthaistnu meelest kuidagi kokku ei sobi. Jääaeg ja veeuputus, planeedid ja hingeliblikad, puugid ja lennukid, raamatukogud ja nõiapiiblid kuuluvad samakvaliteediliste osistena algoritmi, mille abil sedasinast maailma arusaadavaks muudetakse. Üldistada võiks umbes nii: pimeduses süttib valgus aegade alguses kõmanud Sõna ja külapoest ostetud elektripirni toel. Minevik ja olevik on koos, pole kunagi lahus olnudki.

Üks mees rääkis, et Petseri kloostri alt läheb maa-alune käik Jeruusalemma: siist kloostrist alt Jumala tehtu tee. Ja sealt rahvast käve enne kaema, seal on kõik alt... eesti aigu jo, aastat sinna viiskümmen tagasi, too rahvas lasti sinna ala käuma ja... ja vaatama ja seda. A' ma ei tia, kuis nü̈d om. Ku kaugõlõ no lastass, no om sial sulõttud vai...

Igal suvel käivat välismaalased bussidega seda käiku vaatamas.

\section{Lõpetuseks}

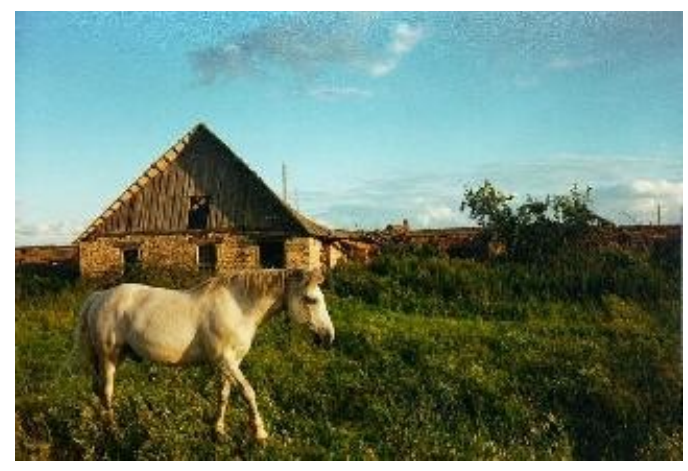

Usuga on siis nii, et kuidas kellelgi. Usutunnistused on erinevad. Üks kuuleb killõt üles tulevat ja lööb risti ette. Teise jutus on kurat rohkem sidesõna eest. Kolmas räägib lugusid eksitajast, puugist jt ja naerab. Usutunnistus seegi.

On selge, et eelnenud jutu põhjal pole mõtet teha järeldusi setu ilmavaate kohta. See, mida (või keda) keegi usub või ei usu, pole tegelikult ikkagi mõõdetav mingite ühikutega. (Võibolla naeru detsibellidega?) Pealegi: kuigi tekstis kasutatud näitematerjal 
pärineb Setumaalt, usun, et tendentsid, mida nende abil ilmestada püüdsin, on omased igale teisenevale kultuurile.

Üldistused ilmavaate essentsist jääksid igal juhul ära. Tuumani ei jõua koore pinnalt analüüse võttes. See, mida mõtlesid ja uskusid need, kes loomisele lähemal, on nende mälus peidus, mitte meie omas.

Ehk on ometi keegi, kes midagi meenutada tahab. Kuid kas sel on mõtet? Ehk ongi nii, et õnn on siit minna jälgi jätmata, minna sinna, kus need, kes olnud enne meid. Aga seegi minek on võimatu, sest neid pole ju unustatud, nad pole kadunud päriselt. Kuidas siis olla samamoodi? Märk on alles, teeviit juhatab algusse. Kas arvame, et oleme teistmoodi, kas usume, et võime minna ja oma jäljed kaasa võtta? Ei saa ju olla ühtaegu viimane teelemineja ja esimene päralejõudja.

Niisiis otsime teid, millel ennegi käidud. Käimata rada on kõle. Käimata rajal käies ei tea sa iial, kas jääd sa ainsaks. Kui äkki ei tulegi keegi. Kes räägib siis tee lõpust? Need, kes läinud, seda ju ei tee. Kummatigi on kahju, kui teised ei tea. Oled vanavarakoguja.

Niisiis lähed. Päike lõõskab. Jalad vajuvad pahkluudeni tolmusesse liiva. Õhk on raske. Jälgi enda ees sa ei näe, kuigi usud kindlasti, et neid peab olema. Aeg on pikk joon, mis keskelt murdunud. Murdunud otsad on teineteisest liialt kaugel, sestap sa ei näegi jälgi. Aga see mõte on su oma olm ja kuigi sa ta õigeksolu ei tea, kõlbab ta su lohutamiseks küll ja nii siis lepidki. Sellele, et lohutuse all on leppimise vajadus, sa ei mõtle. Ei taha üldse ülearu mõelda. Tähtis on vaid põhjuste tabamine, et see aitaks astuda. Kui päike lõhnava heinamaa oma punase lõkendava silma peidab, pead sinagi peatuma. Öösel ju ei näe liikuda, öö on pime ja unenägusid täis. Teedki järelduse, et seda teed käiakse vaid päeval. Aga hommikul oled taas alguses. Tee on jälle sama pikk kui eile. Näed enda jälgi samas tolmus. Nii on igal hommikul: unenägu, mille ööst korjasid, on uus, aga tee endine. Oled meelt heitmas, kuid siiski pead tunnistama, et uni oli kosutav. Lähed jonnaka järjekindlusega uuesti teele. Nii algab see igal hommikul uuesti. Lähed ikka. Pikendad sammu, et õhtuks pisutki kaugemale jõuda. Jõuadki, kuid öö tuleb ikkagi ja hommikul avastad, et selles ruumi piirkonnas ei saa teist päeva olla, et mõõdet, mis järgmise päeva teele ulatuks, polegi. Ei saagi olla, sest sa ihkad ju eilset.

* Tekivad assotsiatsioonid ühe teise, sugugi mitte setu või eesti legendiga: Jeruusalemmast Saalomoni templi alt minevat käik põrgusse. Ka sinna minevat turistid. Aga hirm on ka. Selle ees, kes sealt üles võib tulla.

\section{Kirjandust}

Degh, L.; Vazsonyi, A. 1981. Legend and Belief. Folklore Genres (ed. by Dan Ben-Amos), pp. 93123.

Knuuttila, Seppo 1992. Kansanhuumorin mieli. Jyväskylä.

Masing, Uku 1995. Deemonlik Jumal. Pessimismi põhjendus. Tartu, 1k 9-23.

Masing, Uku 1995. Kaks lugu usust. Pessimismi põhjendus. Tartu, 1k. 285-297.

Mead, M. 1971. Mann und Weib: Das Verhältnis der Geschlechter in einer sich wandelnden Welt. Hamburg.

Propp, V. 1976a. Folklor i deistvitelnost. Moskva.

Spencer, H. 1939. On the Physiology of Laughter. Essays on Education. New York. (1860) 